\title{
Evaluation of Fuel Wood Consumption and Its Implication to Forest Degradation in Agarfa Wereda, South-Eastern Ethiopia
}

\author{
Kasim Adem Mohammed* \\ PFM expert in SOS Sahel Ethiopia, Ziway, Ehiopia \\ Cherinet Seboka Ambaye $(\mathrm{PhD})$ \\ Department of Physics, Collage of Natural \& Computational Science, \\ Madda Walabu University, Bale Robe, Ethiopia \\ Kemal Nure Kawo(MSc.) \\ Department of Statistics, Collage of Natural \& Computational Science, \\ Madda Walabu University, Bale \\ Robe, Ethiopia
}

\begin{abstract}
This study was conducted with the objective of evaluating fuel wood consumption and its implication to forest degradation in Agarfa wereda. The study has employed purposive sampling technique, in which four kebeles were selected based on their settlement patterns, exploitation of the forests and their proximity of kebeles to the town and forest lands. As a result, 134 households were nominated using the simple random techniques. The study utilized primary data, which were collected through household's questionnaires, checklists, and participant observations. Results revealed that about 12 mostly preferred tree species were recorded and identified for fuel wood production. the total amounts' fuel woods consumed by the households were estimated at $65.14 \mathrm{~m}^{3}(39,084 \mathrm{~kg} /$ years $)$. The multiple linear regressions' model was employed. Occupation, household's family members and time spent for fuel wood collection significantly positive linear relationship with fuel wood consumption at $(\mathrm{p}<0.05)$. From the result, fuel woods were to be the second cause of forest degradation next to Agricultural land expansion. The struggles for forest resource's utilization by agricultural households are not adequate to mitigate the problem of forest in spite of some efforts on part of governmental and nongovernmental organizations in mobilizing the household towards forest conservation. In order to confirm sustain sources of fuel wood it is recommended that the use of improved cooking stoves, providing environmental education, increasing income of households, tree planting, encouraged grooviest farming system, providing an alternative form of energy, strengthening law enforcement on part of the government on those who illegally and indiscriminately exploit forest's products, will encouragingly be reducing down the impact of forest degradation and socio-economic conditions of livelihoods of households of study area.
\end{abstract}

Keywords: Deforestation, Forest degradation, Fuel wood consumption, Household

DOI: $10.7176 / \mathrm{JRDM} / 62-03$

Publication date: January $31^{\text {st }} 2020$

\section{Introduction}

\subsection{Background the Study}

Over three billion people of the world lives in rural areas (World bank,2015) with inadequate supply of energy for cooking, lighting, heating, transportation and other purposes. Worldwide, 1.4 billion people have limited access to electricity and 2.7 billion people rely on biomass fuel, mostly in rural areas (IEA,2010). (FAO,2010) revealed that up to 2 billion people depend on forest goods such as fruits, game meat, fibers and fuelwood to meet their basic needs. (FAO,2010) claimed that fuelwood harvesting in developing countries is so important that it rivals other sources of industrial energy such as electricity, principally among poor people in rural areas. In addition, study by (ECA,2013) argued that, 70 percent of people in the developing world rely on wood and it's by products for cooking. Hence in most African countries biomass fuel, especially wood, is the most important source consequently Africa is characterized by strong growth in urban consumption of fuelwood as stated by (Zenebe,2010).

The survival of rural dwellers and urban resident depends on finding enough wood to cook their meal which at present constitutes the main source of cooking fuel for over $76 \%$ of the Nigerian population (Bearer,2008). A study from Ethiopia, which considered regrowth, harvesting of fuelwood and fuelwood consumption, revealed that on a local scale the harvest is three-times the annual allowable cut (Gebreegziabher,2007). Present rate of fuelwood consumption and cutting, may soon convert our forests to savannas and grasslands (Agagu,2009). Many tropical biodiversity hotspots (Bouget,2012) represent such a scenario where human population rely on threatened, reduced and fragmented forests to meet their demand for fuelwood, land for agriculture and production of animal protein (Peres,2010 and Ruger,2008).

Until nowadays Ethiopia is still heavily dependent on traditional fuels (e.g. fuelwood, charcoal, crop residues, 
dung etc.) for domestic energy consumption, especially for cooking. Even in urban areas, cost for electricity and kerosene is unaffordable for many households (Kebede,2002). In rural areas, most households are using fuelwood and charcoal excessively and will turn to more inferior fuels (such as crop residues and dung) when shortage of fuelwood in many areas (Macht,2007).

It is commonly believed that heavy reliance of the households on biomass will bring negative environmental, economic and health impacts. As fuelwood and related wood products "must be collected from the available resource pool, such high dependency is likely to have fundamentally negative impact on the availability of forest resources" (Abebe,2012). In addition, use of crop residues and animal dung when lacking fuel wood deprives the land of essential nutrients, resulting in loss of soil fertility and agricultural output (Gebreegziabher,2007). For instance, unsustainable use of fuelwood, increasing deforestation and soil erosion are major environmental and economic problems facing African countries such as Ethiopia (Nebiyu,2009).

Traditional biomass (wood, charcoal, dung) in household's accounts for roughly $90 \%$ of total primary energy use in Ethiopia (Mekonnen and Kohlin,2009). The imbalance between yield and extraction of wood has caused severe deforestation which further leads to fuelwood scarcity in a global scale (Arnold,2003). In Ethiopia rural households have upgraded their biomass use, from low-quality residues and dung to wood and charcoal (Damte,2012). In urban area, for example, the use of biomass fuel is about 8.2 percent of the total biomass fuel consumption of the country (Dawit,2012).

However, the study area is found in the ecological zone of the Bale Mountains, where large population dependent on forest land for fuel wood consumption. It is obvious from the above that this study is very important in order to improve our knowledge about the level and impact of fuelwood consumption and collection; and to know the extent to which specific plant communities have been depleted of wood conversion for fuel purposes and the amount of possible implication on forest in the study area. This comes down to the facts that the general lack of information limits our ability to draw firm conclusions about the variation of fuelwood collection. For a sustainable natural setting and balanced function of the ecology there is a need to evaluate quantity regarding fuelwood consumption and production in the study area. Therefore, it is obvious that fuel wood consumption is resulting in a visible and alarming rate of degradation of our forest causing great damage to natural resources with specific reference to species and this needs urgent attention by all the stakeholders in study area.

\subsection{Statement of the Problem}

In Ethiopia, fuelwood is the most important source of energy, where 96 percent of the population is dependent on biomass energy sources for cooking and other energy demands (Mekonnen,2012). Such extreme dependence on traditional fuels has its impact on the natural environment. Especially the heavy dependence on fuelwood has multifarious and related problems which have to do with deforestation, land degradation and another circle of fuel wood crisis. In spite of the measures that are being taken at country level in order to rehabilitate the environment, the consumption of biomass fuels has been increasing by 2.5 percent (Mekonnen,2012).

Despite in Ethiopia, fuelwood is widely used in rural areas as well as in urban centers including big towns (Kebede,2002), but the factors influencing the pattern and magnitude of use of these fuels by rural and urban households are still not similar. According to (Yissehak,2012), 80 percent of the urban fuel source is from traditional fuels and in recent years' fuelwood alone contributes almost 56 percent of the total energy consumption of the urban city for example in Addis Ababa. In Ethiopia, an extensive demand for fuelwood is causing a widespread degradation on the existing natural forest including the Bale Eco-Region (BER).

However, the above researchers did not evaluate fuel wood consumption and its implication to forest degradations in Agarfa wereda, Bale Zone as per the investigators' knowledge. Therefore, this study was conducted to fill the research gap of the preceding researchers, by evaluating the quantity of fuel wood used for domestic energy consumption and assessing its implication on forest degradation by household in the Agarfa wereda. Hence, the investigator identified this among other problems in the study area since this problem was one of the crucial issues in the study area.

\subsection{Objectives}

\subsubsection{General objectives}

The main objective of this study is to evaluate fuel wood consumption and its impact to forest degradation in a case of Agarfa district, south east Ethiopia.

\subsubsection{Specific objectives}
i. To evaluate quantity of fuelwood consumption in the study area.
ii. To identify tree species used for fuelwood consumption in the study area.
iii. To assess implication of fuelwood consumption on forest degradation in study area.

\subsection{Significance of the Study}

Fuel wood consumption is regarded as one of the great sources of energy in the developing world, mainly in Africa 
as well as in Ethiopia. Studies show that fuel wood consumption is one of the serious causes of deforestation and the consequent impact on forest degradation in Ethiopia. The study addresses the patterns of household fuel wood and its implication to forest degradation. It could further inform policy makers and potential environmental researchers the impact associated to fuel wood consumption. This study helps as to inform the concerned body about endangered tree species due to household tree preferences for fuel wood collection. It could be informed policy makers and researchers, the factors that were associated with the patterns of demand for wood fuel consumption.

\section{Data and Methodology}

\subsection{Description of the Study Area}

This study was conducted in Agarfa wereda of oromia Region, South east Ethiopia. Agarfa wereda was geographically situated at $7^{0} 17^{\prime}$ to $7^{0} 30^{\prime} \mathrm{N}$ latitude and $39^{\circ} 49^{\prime}$ to $40^{\circ} 00^{\prime}$ E longitude. It found in the extreme North Western Corner of the zone, Agarfa Wereda bounded by Shirka district of Arsi zone in the North, West Arsi zone in south West, Dinsho in south, Sinana in south East and Gasera in North East. The total area of the district is $1258 \mathrm{~km}^{2}(125,800 \mathrm{ha})$ which ranked the district $15^{\text {th }}$ largest districts among the zonal district. It accounts about 1.9 percent of the total areas of the zone.

Figure 1: Map of Agarfa Wereda Showing the Study Area

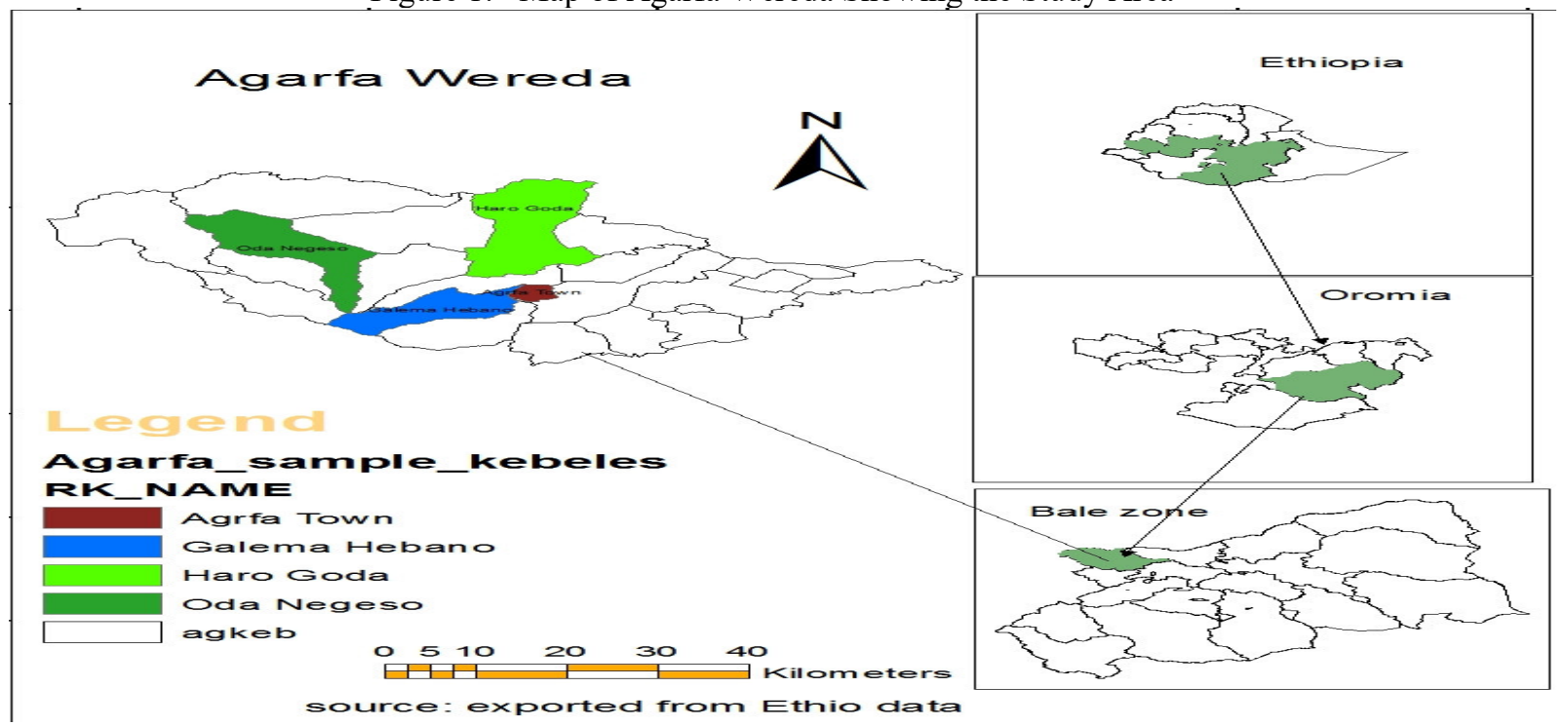

\subsubsection{Biophysical characteristic s of study area}

Sources : Ethio GIS data

Agro-climatically, Agarfa wereda subdivided in to Frost, Highland, Semi-Highland and Lowland. The annual average temperature of the district is about $17.5^{\circ} \mathrm{c}$. In the lowland areas the temperature reaches up to $25^{\circ} \mathrm{c}$ where as in the highland area their temperature less than $10^{\circ} \mathrm{c}$. Thus, the temperature of the district increase from the border areas of south west part of the district to the North West part of the district. In the district, the average annual rain falls are $800 \mathrm{~mm}$ where as $1200 \mathrm{~mm}$ and $400 \mathrm{~mm}$ Maximum and Minimum annual rainfall recorded in the district. The district connected with neighboring district by road transport that passes through Robe -Agarfa and Robe via Jara and Ginir.

\section{Topography}

The topography of the district is more or less plain land, i.e. the land is suitable for mechanized farming. The elevation of the district ranges between $2300 \mathrm{~m}-2700 \mathrm{~m}$ above sea level. The general elevation of the district ranges between nearly $1250 \mathrm{~m}$ along Wabe river course and $2300 \mathrm{~m}$ above sea level.

\section{Population}

The total of population Agarfa district is 124,522. Out of this 63,576 males \& 60,947 are females. The economic base of Agarfa people is predominantly Agriculture with frequent practice of mixed farming which solely dependent on rainfall farming and cattle rearing in small degrees with traditional means of productions.

\section{Drainage}

The water from the district drains in to two major river basin. These are Wabe Shebelle river basin and Genale river basin. In the district, numerous perennial and seasonal rivers have significant importance for local people e.g. for drinking and irrigation.

\section{Vegetation}

According to Agarfa district, Agricultural and Rural Development office 2017 the commonly known types of natural vegetation in the district are coniferous type of natural vegetation such as juniper forest, Podocarpus, 
Hygneia,olea Africana and etc. In the district from about 30,348.88 hectares of land used for various vegetation cover natural forest is (13.31\%), wood land (11.46\%), shrubs and Bush land estimated about (1.64 \%) and land only covered by manmade forest it estimated about $(0.2 \%)$.

\subsection{Social Economic Activities}

\section{Agriculture}

In Agarfa district Agriculture is dominantly practiced in the highland and Semi highland areas of the district, where as Animal rearing (nomadic way of life) is in the lowland and boarder area. Agarfa wereda have two major cropping seasons which is known as Maher and Belg. Cereals, pulses, Oilseed, fruit, vegetables and spice are the known crop grown in the district (BoFED,2006).

\section{Land use and land cover}

Agricultural sector is the main stay to the livelihood of the majority people. According to Agarfa wereda agricultural offices the land use and land cover of the study area are estimated to account Cultivated Land 31.5\%, Grazing Land $5.33 \%$, Forest land is 13.42 and others $49.45 \%$.

\subsection{Data}

Primary data was used for this study in order to achieve the objectives. The data was obtained from randomly selected households, local government administrations (such as kebele leader, kabines etc.) and governmental organizations and professionals working in the area using surveys, questionnaires, key informant interviews, focus group discussions and personal observation. The fuel wood measurements were conducted in fieldwork using spring balance then estimated in a kilogram $(\mathrm{kg})$.

\subsubsection{Method of Data collection and Data Analysis Sampling design}

The purposive sampling method was employed to obtain sampled kebeles, in which there was successive selection of the household within the population. The lists of the households were regarded as a sampling frame. Then sampled households were selected by simple random technique from kebele register. The study was conducted in two phases: the first phase being preliminary survey prior to the main household's fuel wood survey for pilot testing questionnaires and checklist for households and other key informants. This was crucial to enable the investigator to check the relevance and comprehensiveness of the data collection in gathering the required information. This also assisted in modifying some questions, which were used in the main field work. The second phase was the main survey where questionnaires were administered to respondents at households.

\section{Data collection instruments}

Structured questionnaires, key informant interviews, focus group discussions, field measurements and personal observations were used to collect relevant data for this study. The information obtained was used to supplement primary data obtained from the study area.

\section{Household survey}

The questionnaire was the most important means of data collection. It was used in order to obtain valuable information from the respondents. This study used the questionnaire as a key for collecting data that would help to answer the research questions.

A structured questionnaire that includes both closed and open questions was designed and employed to generate quantitative data from the respondents. The questionnaire was prepared for 134 respondent households that helped us to gather detailed information about quantity of fuel wood, sources of fuel wood, species preferred; tree parts utilized, availability or shortages; other alternative's energy used as well as its implications to forest degradation in study area.

\section{Key informant interview}

Key informants were knowledgeable people who knew deeply the study area and about the consumption of fuel wood and its implication to the forest degradation in the chosen study area. The key informants were selected and interviewed purposively.

\section{Focus group discussion (FGD)}

Focus group discussion was a vital for research method to gather a diversity of information from different segments of the community. The main purpose of FGD was to gain insights and understanding about the fuel wood sources, tree species preference, fuel wood consumption and its implication to forest degradation. The focus group discussions took place when the respondents were available and whenever it was convenient for the participants of the group.

\section{Sample size and Sampling Techniques}

There are nineteen rural and three urban administrative Keebles in Agarfa wereda. Out of these three were nominated based on their settlement patterns, intensive use and exploitation of forest products and one town was selected based on their proximity to individual kebeles and forest lands. The sample sizes of 134 households were selected randomly from the total of 4056 study population from their respective Kebele registers without 
replacement using sample size determination formula developed by (Kothari, 2004). Mathematically, the sampled was determined using the following formula:

$n=\frac{\mathrm{NZ}^{2} \mathrm{pq}}{\mathrm{E}^{2}(N-1)+\mathrm{Z}^{2} \mathrm{pq}}$

Where, $\mathrm{n}=$ sample size of household.

$\mathrm{P}=0.1$ (proportion of population to be included in sample, that is, $10 \%$ ).

$\mathrm{q}=$ is $1-\mathrm{P}$, that is, $(0.9)$.

$\mathrm{E}=$ is degree of accuracy desired (0.05).

$\mathrm{N}=$ total number of housing units.

$\mathrm{Z}=$ standardized normal variable and its value that corresponds to $95 \%$ confidence interval equals 1.96 . The sampling techniques for the study household are tabulated according to table shown below

Table 1: Sampling Household in the study area.

\begin{tabular}{|l|l|l|}
\hline Name of kebele/town & Total number of household & Household headed \\
\hline Gelama Hebano & 410 & 14 \\
\hline Haro Goda & 558 & 18 \\
\hline Oda Nageso & 908 & 30 \\
\hline Agerfa town & 2180 & 72 \\
\hline Total & 4056 & 134 \\
\hline
\end{tabular}

Source: - Agerfa Administration and Municipal office, 2018.

Moreover, twelve key informants comprising of local elders with indigenous knowledge on fuel wood consumption and its implication to forest degradation, kebele leaders, development agent(DA) and women were selected. Similarly, thirty-six focus group discussion participants were also purposively selected from different sections of the community which include elders and kebele administrators, household heads and development agents who had experience on the past and present trend of fuel wood use of the study area.

Table 2. Sample Size for Key Informant Interview respondents and FGD

\begin{tabular}{|l|l|l|l|}
\hline \multirow{2}{*}{ Position/profession } & \multicolumn{2}{l|}{ Sample respondents } & Sampling technique \\
\cline { 2 - 4 } & Key informants & FGD Participants & \\
\hline Local elders & 9 & 12 & Purposive \\
\hline Household heads & - & 8 & Purposive \\
\hline Kebele administrators & 1 & 4 & Purposive \\
\hline Development agents & 1 & - & Purposive \\
\hline Women household & - & 12 & Purposive \\
\hline Werada energy expert & 1 & - & Purposive \\
\hline Total & 12 & 36 & \\
\hline
\end{tabular}

\section{Source: Field Survey, 2018}

Fuelwood consumption sampling techniques

In order to determine Households to be studied, they were categorized into three groups based on family size: Small (up to five members), medium (6-10 members) and large families (more than 10 members) to show representativeness. Then sample Households were drawn by a purposive sampling. From each kebeles, nine households were selected, making a total sample size of thirty six (36). To estimate fuelwood consumption, sample households were asked to show stacked fuelwood bundles for household cooking and heating. From the bundles, based on the family size, 1-2 bundles were weighed and separated from the rest of the fuelwood. Then the respondents were requested to use for the household energy from the weighed bundles for the next six days. After six days, the remaining fuel wood weighted again for consecutive weeks in a month. After physically weighing of fuelwood, it was divided by family size to determine per capita consumption. Three days were selected to minimize factors such as cooking time, guest appearance and heavy meal cooking. The amount of fuel wood consumed at a household level was estimated by measuring bundles of fuel wood in kilograms $(\mathrm{kg})$ using a spring balance.

\subsection{Data analysis}

Quantitative data

In order to answer the research questions, quantitative data was used for this investigation. A method was used to quantify numerical data relating to the study, which was obtained from open and closed-ended questions. Data collected through the structured questionnaires was coded to facilitate data entry into the computer. Data analysis was done by using SPSS software tools from which tables, frequencies and percentages were generated. The Multiple linear regression model was employed to test the relationship between fuel wood consumption and independent variables, which included: family size, education level, time spent in fuel wood collection, distance walked to sources of fuel wood, and occupation of respondents. 
The multiple linear regressions model applied was based on (Mendenhall,1989) formulae's follow:

Where: $\alpha=$ constant

$$
\mathrm{Y}=\alpha+\beta_{1} \mathrm{X}_{1}+\beta_{2} \mathrm{X}_{2}+\beta_{3} \mathrm{X}_{3}+\beta_{4 \mathrm{X}_{4}}+\ldots+\beta_{\mathrm{n}} \mathrm{X}_{\mathrm{n}}+\varepsilon
$$

$\varepsilon=$ error term

$\mathrm{Y}=$ wood fuel consumption as dependent variable $\left(\mathrm{m}^{3}\right)$

$\beta_{1}$ to $\beta_{\mathrm{n}}=$ regression coefficients,

$\mathrm{X}_{1}=$ average size family members at households,

$\mathrm{X}_{2}=$ level of education,

$\mathrm{X}_{3}=$ occupation (Farmers, government employers and merchant or trader)

$\mathrm{X}_{4}=$ time spent for collection (hour)

$\mathrm{X}_{5}=$ distance walked to sources of fuel wood

The regression was tested at $5 \%$ level of probability. The model was preferred because it offers full explanation to the dependent variables since few phenomena are the product of a single cause and the effect of the particular independent variable (Mendenhall,1989).

\section{Fuelwood consumption estimation}

The amount of fuel wood consumed at a household level in the study area was estimated by measuring a bundles (loads of donkey) fuel wood in kilograms $(\mathrm{kg})$ using a spring balance. The quantities of fuel wood loaded on a donkey were measured by spring balance in a kilogram $(\mathrm{kg})$.

$$
\frac{\text { Wwb - Wwl }}{\text { Npp }}
$$

Where:

Wwb - Weight of wood at the beginning of the week

Wwl - Weight of wood left by the end of the week

Npp - Number of people in the household

The conversion factor from $\mathrm{kg}$ to $\mathrm{m}^{3}$ by $($ Steel,1997) found that mean of weight fuel wood (fire wood and charcoal) consumption by a household per annum was calculated as: $1 \mathrm{~m}^{3}$ air dry tropical hard wood weighs $600 \mathrm{~kg}$.

\section{Results and Discussions \\ Sex of the respondent}

The sex distributions of the households were varied. Of the total households included in the survey the majority, $73.9 \%$ headed households were male while the others $26.1 \%$ of headed households were female. During an interview when unable to reach household at home, the female was interviewed as household of the family. These are the reasons why the numbers of female household increasing by $26.12 \%$ in the study area. During focus group discussions (FGD) confirmed that women are often extensively involved in several forests based livelihood activities such as a collection of fuel wood and charcoal production, etc.

\section{Level of education}

Educational status of the community influences household decisions, which determines the well-being of the community. Education is one of the factors affecting fuel wood consumption and their outlook towards using forest resources. The key informant point out that, the more educated family preferred dead or wind fell trees for fuel wood; they were also searching for energy-saving stoves and collecting dried wood for household energy consumption, as well as had established wood lot compare to family with uneducated, which is relatively harvesting fuel wood by cutting green wood.

\section{Occupations}

\section{Source: - Field survey, 2018}

Of 134 interviewed respondents, $82.84 \%$ of the household heads are engaged in farming practices as their main income sources; while $8.96 \%$ respondents were government employed and followed by the remaining $8.2 \%$ of the respondent who were merchant or trader (Figure 3). This finding revealed that majority of a respondent primarily dependent on farming practices for their livelihood. FGD said that, to make appropriate consumption of fuel wood energy and practices, for instance, agro-forestry appeared to be applicable options for forest enhancement and meeting the immediate and long term forest products claimed e.g. fuel wood consumption for communities in the study area. 
Figure 2: Occupation of study household of the study area

\section{Fuelwood use Patterns}

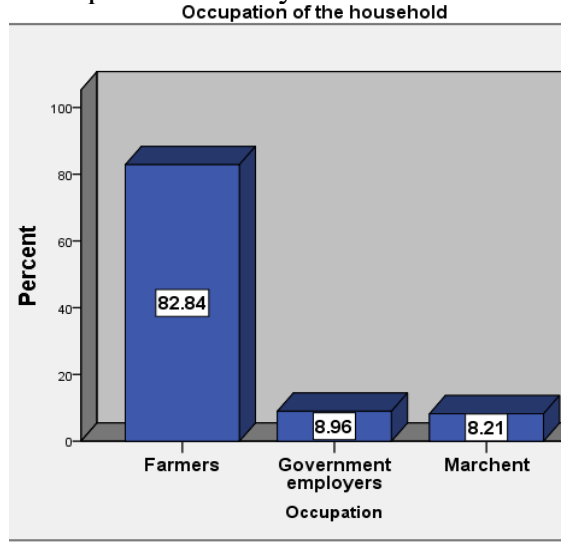

Source: - Field survey, 2018

Worldwide fuel wood was used in combination with other alternative sources of energy since there was the shortage of fuel wood. Result indicating that fuel wood was found to be consumed at households accounting for $63.4 \%$, followed by animal dung with about $14.9 \%$. Similarly, charcoal, crop residues and electricity accounted for about $8.96 \%, 7.46 \%$ and $5.22 \%$ respectively and no one had access to bio gas technology in study area (Figure $5)$. The fuel wood seems to be preferred by the majority of respondents in the study area for cooking and lighting due to easily availability (ranked as first). Socio-economic factors do influence the energy use patterns by households, which include: purchasing power of households, the availability and reliability of the fuel suppliers, its prices, family size and cooking habits. These could be among the reasons for these results obtained from study.

Figure 3: Percentage consumption of fuel wood sources in the study area.

\section{Source of fuel wood}

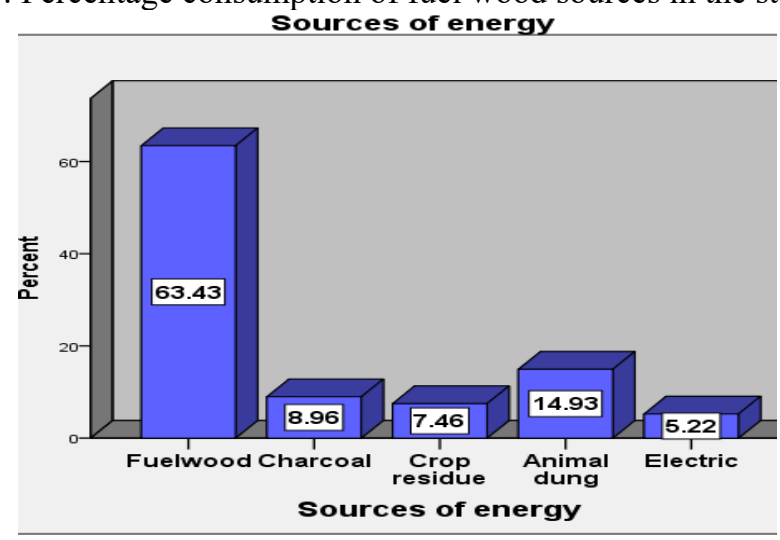

Source: - Field survey, 2018

According to their accessible to the forest household search's on different sources for fuel wood collection. For instance, certain household harvested fuel from forest or forest reserve whereas the others collected from their own woodlot around their homestead. Finding revealed that, the majority of the households in study area are mainly reliant on fuel wood collected from natural forest as sources of domestic energy and to supplement livelihood income generation.

Finding shows below in Figure 4, with the percentage of $60.45 \%$ respondents were reliant on fuel wood collected from natural forest, followed by $22.39 \%$ of respondent household who were collected fuel wood from forest reserves as a source's house energy consumption and supplied to the market in order generate their income; however, $8.21 \%$ of the households had been collecting wood from their own woodlots for house energy. Similarly, the remaining $8.96 \%$ of the household were bought fuel wood from the neighbor market. 
Figure 4: Percentage Collection sources of fuelwood in the study area

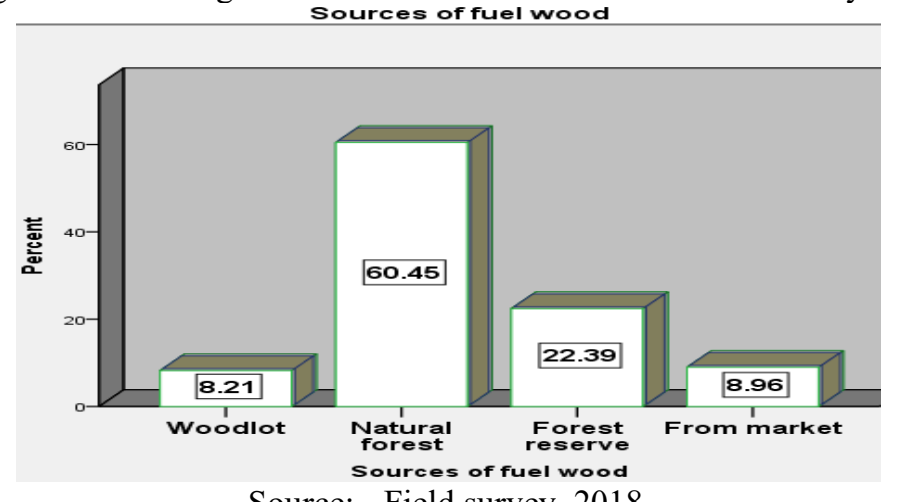

Type of collected fuel wood.

Source: - Field survey, 2018

Unusual types of fuel wood were used for energy consumption in the study area. Based on availability of fuel wood, mainly households were preferred distinctive types of fuel wood such as dried wood, green and both woody type. Results reveal that, $84.21 \%$ of the respondents found to be collecting fuel wood by cutting leafy wood, followed by $9.02 \%$ of the household who were collected fuel wood by cutting both green and dried wood; only $6.77 \%$ of respondents were collected the dry wood.

Due to depletion of forest resources in Ethiopia, particularly in the study area small group of households who live closer to natural forest were strongly preferred to collect dry fuel wood because of its easy availabilities. Therefore, spending short time and distance walked in collecting fuel wood; however, the majority of respondents were preferred to cut green wood. This indicates there is a shortage of fuel wood in the areas (Figure 6). This created serious forest degradation due to the increasing market demand and sellers' groups over the fuel wood from the area by cutting green wood.

Figure 5: Type of fuel wood collected in the study area

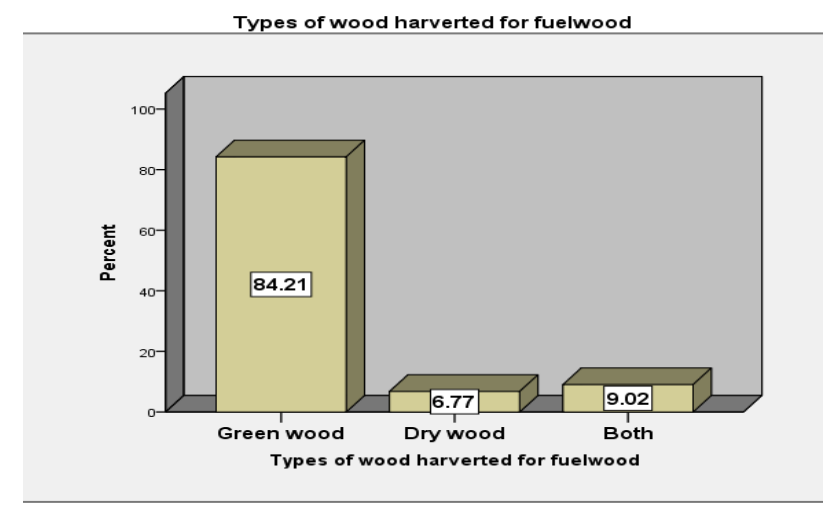

\section{Quantity of fuel wood consumed}

Sources: Field survey,2018

All thirty-six surveyed household reported using fuelwood regularly as their only source of cooking and house heating. The fuelwood consumption of each group of HHs categorized by their kebeles is presented in (Table 4). The overall average of daily per capita fuelwood consumption was $11.95 \mathrm{~kg}(4361.75 \mathrm{~kg} / \mathrm{person} / \mathrm{year})$. The House holds fuelwood consumption decreased from rural to urban: $14.71,13.79,11.66$ and 7.64kg/person/month for Oda Nageso, Galama Hebano, Haro Goda and Agerfa town, respectively. However, the per capita fuelwood consumption decreased with increasing availability of alternative energy sources. The highest fuelwood consumption per day per person was $0.46 \mathrm{~kg}$ (Oda Nageso) and the lowest was $0.25 \mathrm{~kg}$ (Agerfa town). 
Table 4: Quantity of fuel wood consumed in the study area

\begin{tabular}{|c|c|c|c|c|c|c|c|}
\hline Address & $\begin{array}{l}\underline{7} \\
\dot{0} \\
\overline{0}\end{array}$ & $\begin{array}{l}\sum_{i}^{\infty} \\
\dot{0}\end{array}$ & $\begin{array}{l}\text { WFWC } \\
\text { (kg) }\end{array}$ & $\begin{array}{l}\text { WFWL at } \\
\text { of end } \\
\text { the month( } \\
\text { kg) }\end{array}$ & $\begin{array}{l}\text { AWFWC } \\
\text { in } \\
\mathrm{kg} / \text { month) }\end{array}$ & $\begin{array}{l}\text { Total weight of } \\
\text { fuelwood } \\
\text { cons.kg/ year }\end{array}$ & $\begin{array}{l}\text { AWFWC in } \\
\mathrm{kg} / \text { year) }\end{array}$ \\
\hline $\begin{array}{l}\text { Gelama } \\
\text { Hebano }\end{array}$ & 9 & 66 & 962 & 52 & 13.79 & 10920 & 5033.35 \\
\hline Agerfa Town & 9 & 64 & 504 & 15 & 7.64 & 5868 & 2788.6 \\
\hline Oda Nageso & 9 & 70 & 1036 & 6 & 14.71 & 12360 & 5369.15 \\
\hline Haro Goda & 9 & 71 & 844 & 16 & 11.66 & 9936 & 4255.9 \\
\hline Total & 36 & 271 & 3346 & 89 & 47.80 & 39,084 & 17447 \\
\hline Average & & & 814.25 & 22.25 & 11.95 & 9,771 & 4361.75 \\
\hline
\end{tabular}

\section{Source: kitchen measurement, 2018}

Where: - No. $\mathrm{HH}=$ number of household, No. FMS $=$ Number of family members WFWC $=$ weight of fuel wood consumed, WFWL= weight of fuel wood left,

AWFWC $=$ Average weight of fuel wood consumed, $\mathrm{Kg}=$ kilogram

Accordingly, annual quantity of fuel wood consumed by households in the study area was estimated that $65.14 \mathrm{~m}^{3}$ $(39,084 \mathrm{~kg} /$ years $)$. The average weight of fuel wood per household head was estimated at $(1.36 \mathrm{~m} 3) 814.25 \mathrm{~kg}$ per months.

Parts of tree utilized for fuelwood

As mentioned above under the topic of species preference, for instance, depending on availabilities, access and distance from forest, fuel wood collector selectively utilized different part of a tree for house energy consumption. The specific part of a tree, e.g. stem, branches, leaves and root were preferred by fuel wood collectors. Results revealed that, with $73.9 \%$ of the respondent utilized stem part, followed by branch with $20.9 \%$ and with $3.7 \%$ of the respondent preferred leave for household energy consumption but, only $1.5 \%$ household were preferred root for fuel wood energy.

Figure 6: Tree Part Utilized for Fuel wood

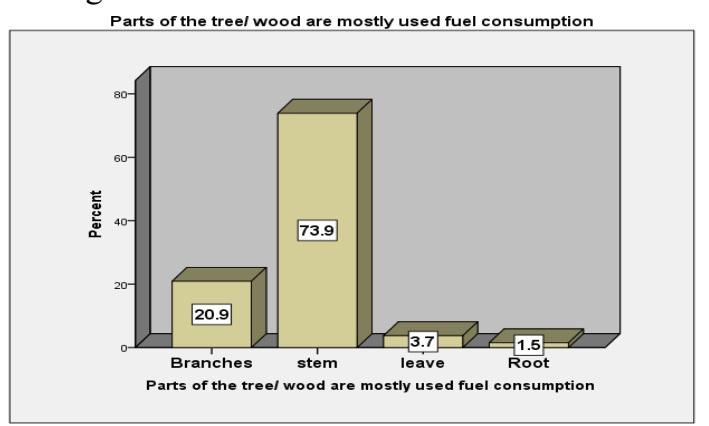

Source: - Field survey, 2018

\section{Factors influencing fuel wood consumption}

Results indicate that fuel wood consumption in the study area has been influenced with its availability, which is confirmed by $53.0 \%$ of the respondents, followed with $38.1 \%$ who mentioned inadequate alternative energy sources. Whereas the rest $9 \%$ of the respondent are mentioned price as factor influencing fuel wood consumption in study area.

Table 5: Factors influencing fuel wood consumption

\begin{tabular}{|l|l|l|}
\hline Factor affecting fuel wood & Frequency & Percent \\
\hline Availabilities & 71 & 53.0 \\
\hline Price & 12 & 9.0 \\
\hline Inadequate alternative energy sources & 51 & 38.1 \\
\hline Total & 134 & 100.0 \\
\hline
\end{tabular}

Source: - Field survey, 2018

Generally, key informant noted that the study area was previously covered with sufficiently vegetation where before the areas aimed for crop production and other practices such as fuel wood production, encroachment and grazing land. This is a typical an example showing that forests and its products, including fuel wood were available and collections were taken for granted as allowed access commodity within the vicinity areas. 
The availability of fuel wood has been the implication on per-capita consumption to be increasing as well as the user tends to use forest products, including fuel wood unsustainable; consequently, they have to threaten the land through degradation and deforestation. Results revealed that fuel wood availability was relatively site specific Multiple linear regressions

The models are examining the relationship between a dependent variable and independent variables Table 6. Model Summary ${ }^{\text {a }}$

\begin{tabular}{|l|l|l|l|l|}
\hline Model & R & R Square & Adjusted R Square & Std. Error of the Estimate \\
\hline 1 & $.396^{\mathrm{a}}$ & .157 & .124 & .967 \\
\hline
\end{tabular}

a) Predictors: (Constant), Time spend to collect fuelwood per day, level of education, Distance walked to sources for fuelwood collection, Household family size, Occupation of household

The multiple correlation determinations also show as R squared is 0.157 , meaning that approximately $15.7 \%$ of variability of load of fuel wood accounted by variables in the model. The adjusted R-squared indicates that about $12.4 \%$ of the variability a load of fuel wood accounted for by the model; even though after taking into account the number of predictor variables in the model.

Table 7. ANOVA ${ }^{\mathrm{a}}$

\begin{tabular}{|l|l|l|l|l|l|l|}
\hline \multicolumn{2}{|l|}{ Model } & Sum of Squares & Df & Mean Square & F & Sig. \\
\hline \multirow{4}{*}{1} & Regression & 22.232 & 5 & 4.446 & 4.758 & $.001^{\mathrm{b}}$ \\
\cline { 2 - 7 } & Residual & 119.626 & 128 & .935 & & \\
\cline { 2 - 7 } & Total & 141.858 & 133 & & & \\
\hline
\end{tabular}

a. Dependent Variable: A load of fuelwood consumed(permonth)

b. Predictors: (Constant), Time spend to collect load of fuel wood per day, Level of education, Distance walked to supply sources for fuelwood collection, Household family size, Occupation of Household.

The p-value of the F-test to see if the overall model is important, with a p-value less than 0.05 , meaning the model is statistically significant.

Table 8. Coefficients ${ }^{\mathrm{a}}$

a. Dependent Variable: A load of fuelwood consumed (permonth)

\begin{tabular}{|c|c|c|c|c|c|c|c|}
\hline \multirow[t]{2}{*}{ Model } & \multicolumn{2}{|c|}{$\begin{array}{l}\text { Unstandardized } \\
\text { Coefficients }\end{array}$} & \multirow{2}{*}{\begin{tabular}{|l}
$\begin{array}{l}\text { Standardized } \\
\text { Coefficients }\end{array}$ \\
Beta
\end{tabular}} & \multirow[t]{2}{*}{$\mathrm{t}$} & \multirow[t]{2}{*}{ Sig. } & \multicolumn{2}{|c|}{$\begin{array}{l}95.0 \% \text { Confidence } \\
\text { Interval for B }\end{array}$} \\
\hline & $\mathrm{B}$ & Std. Error & & & & $\begin{array}{l}\text { Lower } \\
\text { Bound }\end{array}$ & $\begin{array}{l}\text { Upper } \\
\text { Bound }\end{array}$ \\
\hline (Constant) & 2.018 & .151 & & 13.340 & .000 & 1.719 & 2.317 \\
\hline Occupation & .328 & .145 & .190 & 2.270 & .025 & .042 & .614 \\
\hline Household family size & .210 & .103 & .169 & 2.038 & .044 & .006 & .415 \\
\hline Level of education & -.247 & .109 & -.187 & -2.260 & .026 & -.464 & -.031 \\
\hline $\begin{array}{l}\text { Distance walked for fuelwood } \\
\text { collection source }\end{array}$ & -.306 & .134 & -.187 & -2.285 & .024 & -.571 & -.041 \\
\hline $\begin{array}{l}\text { Time spend to collect a load of } \\
\text { fuelwood per day }\end{array}$ & .204 & .088 & .194 & 2.322 & .022 & .030 & .377 \\
\hline
\end{tabular}

The coefficients for each of the variables indicate the amount of change one could expect in a load of fuel wood consumption given a one-unit change in the value of that variable, given that all other variables in the model are held constant. One could expect an increase of 0.204 in a load of fuel wood consumption for every one-unit increase in time spends to collect fuel wood per day, assuming that all other variables in the model are held constant. Beta coefficients, also known as standardized regression coefficients are used to compare the strength of a given coefficient to the coefficient for another variable.

In this analysis, for example, time spends to fuel wood collection has the largest $\beta$ coefficient, around 0.194 , and household family size had the smallest $\beta, 0.169$. Thus, a one standard deviation increase in time spends to fuel wood collection leads to a 0.194 standard deviation increase in predicted fuel wood consumption, when the other variables held constant. And, a one standard deviation growth in house hold family members, in turn, leads to a 0.169 increasing in fuel wood consumption when the other variables in the model held constant. For example, a one standard deviation decrease in education level would yield a 0.247 standard deviation increase in the predicted fuel wood consumption. Household occupation, household family size and time spent to fuel wood collection had positive relationship to fuel wood consumption in the study area. Level of education and distance walked to sources of fuel wood collection had negative relationship to fuel wood consumption of household in the study area. In generally, since a p-value greater than 0.05 , we conclude that the overall model is significant relationship to fuel wood consumption.

Major causes of forest degradation

According to table 9, the conversion of forest land to agricultural land, the rising demand over tree product for fuel 
wood and charcoal, the population pressure, lack of income, a need for construction materials, demands for grazing land and lack of income are the major factors contributing to the fast disappearance of the natural forest in the districts

Table 9. Major causes of forest degradation perceived by respondents

\begin{tabular}{|l|l|l|l|}
\hline Causes of forest degradation & $\begin{array}{l}\text { Frequency } \\
(\mathrm{N}=134)\end{array}$ & Percent of Cases & Ranks \\
\hline Agricultural land expansion & 122 & $91 \%$ & $1^{\text {st }}$ \\
\hline Fuel wood production & 110 & $82.1 \%$ & $3^{\text {rd }}$ \\
\hline Charcoal making & 30 & $22.4 \%$ & $7^{\text {th }}$ \\
\hline Getting grazing land & 38 & $28.4 \%$ & $6^{\text {th }}$ \\
\hline Population pressure & 111 & $82.8 \%$ & $2^{\text {nd }}$ \\
\hline For construction & 81 & $60.4 \%$ & $4^{\text {th }}$ \\
\hline Lack of income & 55 & $41 \%$ & $5^{\text {th }}$ \\
\hline
\end{tabular}

Source: - Field survey, 2018

Results revealed that agricultural land expansion accounted (91\%); followed by population pressure (82.8\%), fuel wood production $(82.1 \%)$, collection of construction wood $(60.4 \%)$, lack of income $(41 \%)$, grazing land share accounts $(28.4 \%)$ and the production of charcoal (22.4\%). All the respondents argued that forest fires were not the big problem because of nonappearance for fire incidences in the study area.

One of the key informants described that "there was higher population growth in his locality, which brought about high demand for fuel wood, construction wood and cultivable land. Others of the key informants and FGD argued that described, poor and landless people encroached to marginal forest land and steep slopes in search for cultivation and grazing land which, contributed to forest destruction." They further added that, over exploitation of forest resources through household, daily activities caused the shortage of fuel wood in which people had to travel a long distance in search of it.

\section{Implication on forest degradation}

\section{Impact of fuelwood consumption on Forest}

When carried out on unmanageable basis of fuelwood harvesting, leads to a wide range of local and global environmental impacts, including forest degradation, loss of biodiversity leading to soil erosion, changes in nutrient cycles, and emissions of greenhouse gases. The finding in Figure 11 below which reveals that wood removal for fuelwood components lead to deforestation $(34.33 \%)$, loss of valuable species $(19.40 \%)$, loss of productivity $(23.13 \%)$, loss of soil fertility $(14.93 \%)$ and global warming $(8.21 \%)$ respectively. Focus Group Discussion (FGD) and personal observation during the ecological surveys revealed that there has been considerable decrease in the vegetation cover in the study area in terms of number and species diversity. In fact, all the indigenous trees noted for the area, such as Juniperus procera, Podocarpus falcatus, Olea Africana, and Hygenia abyssinica spp. have susceptible to disappeared and partly the area is currently converted in to farm land.

Figure 10: Respondents Perception on Environmental Impacts of Fuelwood

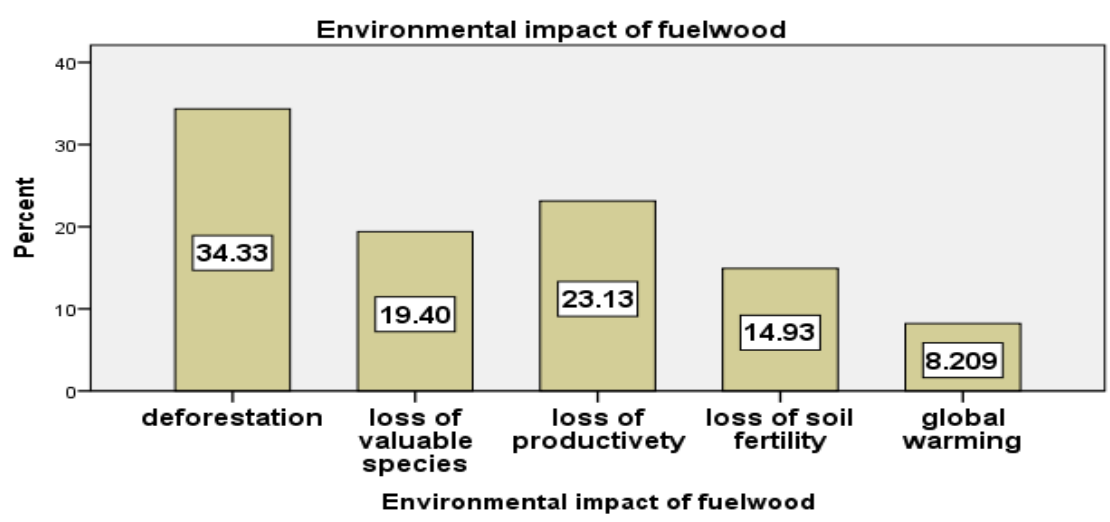

Tree species preference for fuelwood.

The preference of tree species, mostly dependent fuel quality and availability, but the quality may vary greatly. For instance, some species burn fast; while Other species may produce a lot of exasperating smoke or be very difficult to dry well sufficiently. Finding revealed that these species are preferred for fuel because of their attributes such as smokiness and long-lasting flame. The most appreciated for cooking are those species with a heavy wood that burns slowly with a lot of heat and little smoke. Some of the respondents admitted, specifically the fuel wood collectors, that breakable branches, a fast drying time and flammability were important factors taken into consideration when selecting fuelwood species. 
Table 10: Tree species preferred by household in the study area

\begin{tabular}{|l|l|l|l|}
\hline No. & Tree species preferred for fuel wood mostly & Frequency & Percentage \\
\hline 1 & Juniperus procera(gaatira habashaa) & 53 & 39.6 \\
\hline 2 & Podocarpus falcatus (Birbirsa) & 38 & 28.4 \\
\hline 3 & Olea europeae(ejersa) & 8 & 6 \\
\hline 4 & Maytenus gracilipes (Kombolcha) & 15 & 11.2 \\
\hline 5 & Nuxia congesta(Bixannaa) & 5 & 3.7 \\
\hline 6 & Hagenia abyssinica(Heexoo) & 4 & 3 \\
\hline 7 & Croton macrosstachyus(makkanisaa) & 2 & 1.5 \\
\hline 8 & Erythrococca abyssinica(Irqammuu) & 1 & 0.7 \\
\hline 9 & (Tullaa) & 1 & 0.7 \\
\hline 10 & Pittosporus abyssinicum (Aara) & 2 & 1.5 \\
\hline 11 & Acacia abyssinica(laaftoo) & 1 & 0.7 \\
\hline 12 & Maesa lanceolataForssk(Abayii) & 4 & 3 \\
\hline Total & & 134 & 100 \\
\hline
\end{tabular}

Source: Field data collection, 2018

According to the household views, Juniperus Procera and Podocarpus falcatus are highly preferred for energy consumption. This situation was proofed by observing from the everyday supply of fuel wood from the forest. The dependence of the community more on the two species for fuel wood was day to day needs, so that it creates high pressure on degrading the status of the tree species in the forest. Their growth habit is very slow, and the extraction of the two species is also high. Therefore, the implication on the forest was that this species may go into extinction in that order, if this demand continued to be high without any mitigation strategy in place.

\section{Discussions}

Finding revealed that ages between 20 to 60 years regarded as the most active working age in study area. This implied that, labor resources in most households were sufficient for activities like farming, fuelwood collection and charcoal production for income generation. On other hand FGD argued that young aged between 20 to 60 years more dependent on fuelwood and its related activities as their main employment opportunity for their livelihood sustaining. This study supported by (Makwaia,2003), reported that the age of individuals between 15 to 44 plays an important role in application of indigenous knowledge and innovations, which could have either negative or positive impact to forest resources conservation, Afforestation, deforestation, and encroachment of restricted area.

Result shows that some olea species with regardless of its availablity were noted to be used for fuelwood consumption was threatened species in study area. This finding was similar with $(\mathrm{FAO}, 2010)$, reported that consumption of fuelwood regardless of species importance as source of energy for cooking indicates fuelwood scarcity in a particular local area.

Results from regression analysis showed that independent variable such as time spend to collect fuel wood, household family size and occupation showed positive significant while education level and distance walked in fuelwood gathering showed negatively significant. This study supported by (Abebaw,2007; Jumbe and Angelsen,2011). Results showed that households education level had negative relationship with fuelwood consumption. This implies that the increase education level of the household's head of the study area seem to be corresponds to the decrease quantity of fuel wood consumption at the households. This could be supported by argument that they can adopt the use of efficiently fuel wood cooking stoves, consequently, the less quantity of fuelwood to be consumed by households (Abdallah,2007).

There was a significant and positive relationship between fuelwood consumption and the family size in the study area. The positive correlation implies that the households with more people often tend to use more fuel wood. This study is Similar with studies in Ambo district by (Abaynesh,2015) reported that an amount of energy consumption for domestic cooking increases with the increment of family size and is highly significant. Household members particularly women and children engaged in collecting fuelwood to meet the burden associated with fuelwood gathering. In the study area indicating that women and children take more time, collecting fuelwood, which was formerly readily available close to homesteads. This study supports (Arnold,2003) argued that women and children are responsible for collection of fuelwood, and that increases the burden on these household members in particular.

Finding reveal that, the annual quantity of fuelwood consumed by households in the study area was found to be $65.14 \mathrm{~m}^{3}(39,084 \mathrm{~kg} /$ years $)$. The mean of daily fuelwood consumption per capita was $11.95 \mathrm{~kg}(4361.75$ $\mathrm{kg} / \mathrm{person} / \mathrm{year}$ ) in study area. Which is comparatively higher than similar studies conducted by (Abaynesh,2015) reported that $3.2 \mathrm{~kg}(1168 \mathrm{~kg} /$ person/year) was the mean of daily fuelwood consumption per capita in Ginch oromia zone. 
Furthermore, FGD added that people collected fuel wood daily either for home consumption or selling in towns like Agerfa, Ambentu and Ali small town. In relation to this, most of the key informants noted that the household are collecting a lot of fuelwood to prepare food and heating their houses when there were lack alternative energy sources in their locality. This finding similar with the study conducted by (Solomon, 2005).

The uncontrolled increase in population led to the clearing of forests cover to produce crops. Among the respondents, $91 \%$ indicated that the agricultural expansion is the major reason for forest degradation, while $82.1 \%$ believed that fuel wood collection is the third main cause in the study area. The result is similar with the finding of study conducted at Goba Woreda in which $96.7 \%$ of the respondents perceived that the lack of farm land as being the major reason for deforestation (Girma,2015).

\section{Conclusion and Recommendations \\ 4.1 Conclusion}

Study revealed that, $63.4 \%$ of the households in study area used fuel wood as the principal energy source for cooking and heating. Besides this agricultural crop residues and animal dung to particular level were used for cooking at some households during the harvesting period, which indicating the fuel wood scarcity in the study area. The mostly preferred tree species for fuel wood consumption (Juniperus Procera, Podocarpus falcates, Maytenus gracilipes and Olea europiana) was recorded and identified in the study area.

Fuelwood consumption was influenced by many factors such as the household's family size, occupation, education level, time spent in collection and distance the household traveled to the sources which significantly indicating both negative and positive relationship to the fuel wood consumption. Rural households collect fuel wood daily for both home consumption and getting income to satisfy their basic needs. The high demand for fuel wood both in the rural and urban area aggravated the forest resources to be degraded continuously. Moreover, the shortage of alternative energy source like bio gas, solar energy and electric energy other than fuel wood could have led these households for further forest destruction.

\subsection{Recommendation}

There is a need to prepare local community participation at the kebele level as the bottom-up approach, pay attention in gender balance in planning and decision making on planting activities, natural resource protection and utilization to be effective and sustainable.

The implications on the environmental are obvious: deforestation, declining agricultural productivity and destruction of the ecological systems leading to loss of bio diversity and important wildlife. In order to address such unattractive communal, financial and natural consequences, various interventions such as promotion of improved energy technologies; community awareness creation on consequences of forest degradation associated with fuel wood consumption and other alternative modern energy supplies are recommended assuming the existing technology.

\section{References}

Abaynesh, 2015. Effect of firewood energy consumption of households on deforestation in Debis watershed Ambo district, Oromia Regional State, Ethiopia. World Applied Sciences Journal, 33(7), pp.

Abdallah, J.M., Mombo, F.M., Mgumia, F.H., Kingazi, S.P. and Mathew, M., 2007. Household energy crisis and woodfuel consumption in urban areas: the case of IIala district, Dar s Salaam. Tanzania. Journal of Tanzania Association of Foresters, 11, pp.78-86.

Abebaw, D., 2007. Household determinants of fuelwood choice in urban ethiopia: a case study of Jimma town. The Journal of Developing Areas, pp.117-126.

Abebe and Girma, E., 2012. Self-care behavior among patients with diabetes in Harari, Eastern Ethiopia: the health belief model perspective. PloS one, 7(4), p. e35515.

Agagu K.O.,2009. 7th Chief S.L Edu Memorial Lecture. Threats to the Nigerian Environment: A Call for Positive Action.

Arnold, M. and Kohlin, G.,2003. Fuelwood revisited. What has Changed.

Bearer S.,2008. Effects of fuelwood collection and timber harvesting on giant panda habitat use. Biological Conservation, 141, 385-393.

BoFED, 2016.National Regional Government of Oromiya Bureau of Finance and Economic Development. Physical and Socio Economic Profile of Bale Zone and 21 Districts, Finfine

Bouget, C., 2012. Effects of fuelwood harvesting on biodiversity - a review focused on the situation in Europe. Canadian Journal of Forest Research, 42(8), pp.1421-1432.

Damte, A. and Mekonnen, A.,2012. Coping with fuelwood scarcity: household responses in rural Ethiopia. Environment for development discussion paper series vol. EfD DP, pp.12-01.

Dawit. 2012. Application of an almost ideal demand system (AIDS) to Ethiopian rural residential energy use: Panel data evidence. Energy policy, 50, pp.528-539. 
ECA.(2013). African Economic Outlook.

FAO. 2010. Global Forest Resource Assessment, 2010. Main Report FA Forestry Paper. Food and Agricultural Organization United Nations, Rome.

Gebreegziabher, Z. 2007. Household fuel consumption and resource use in rural-urban Ethiopia. Wageningen Universiteit (Wageningen University).

Girma Assefa,2015. Aspects of deforestation and efforts of forest conservation in selected kebeles of Goba Wereda, Bale Zone, Oromia Regional State. Haramaya University, Ethiopia.

IEA.2010. Analysis of the Scope of Energy Subsidies and Suggestions for the G-20 Initiative, pp.26-27.

Jumbe, C.B. and Angelsen, A., 2011. Modeling choice of fuelwood source among rural households in Malawi: a multinomial probit analysis. Energy Economics, 33(5), pp.732-738.

Kebede, B., 2002. Can the urban poor afford modern energy? The case of Ethiopia. Energy policy, 30(11-12), pp.1029-1045.

Kothari, C.R., 2004. Research methodology: Methods and techniques. New Age International.

Macht, C., 2007. Household Energy Consumption: Community Context and Fuelwood Transition. Michigan, USA, University of Michigan, Population Studies Centre, Institute for Social Research: 23pp

Makawia, I.A., 2003. Contribution of Agroforestry to Human nutrition: A case study of Majiya Chai, Kikatiti and Kisongo in Arusha Region, Tanzania (Doctoral dissertation, Dissertation for Award of MSc Degree at Sokoine University of Agriculture, Morogoro, Tanzania. 124pp).

Mekonnen, A. and Köhlin, G., 2009. Determinants of household fuel choice in major cities in Ethiopia.

Mekonnen, A., 2000. Valuation of community forestry in Ethiopia: a contingent valuation study of rural households. Environment and Development Economics, 5(3), pp.289-308.

Mendenhall, M., 1989. A practical but theory-based framework for selecting cross-cultural training methods. Human resource management, 28(4), pp.511-539.

Nebiyu, A., 2009. Domestic energy consumption and deforestation in Harari region assessment of students' awareness and views. School of Graduate Studies. Department of Geography and Environment Education. Addis Ababa, Ethiopia.

Peres, C.A., 2010. Biodiversity conservation in human-modified Amazonian forest landscapes. Biological Conservation, 143(10), pp.2314-2327.

Rüger, N., 2008. Long-term impacts of fuelwood extraction on a tropical montane cloud forest. Ecosystems, 11(6), pp.868-881.

Solomon, A, 2005. Land use and land cover change in headstream of Abbay watershed, Blue Nile basin, Ethiopia. Unpublished Master's Thesis). Addis Ababa University, Addis Ababa, Ethiopia.

Yissehak, A. 2012. sustainable household energy for Addis Ababa Ethiopia in consilience :The journal of sustainable development., 1-11.

Zenebe, 2010. Impact of soil and water conservation measures on catchment hydrological response a case in north Ethiopia. Hydrological processes, 24(13), pp.1880-1895. 


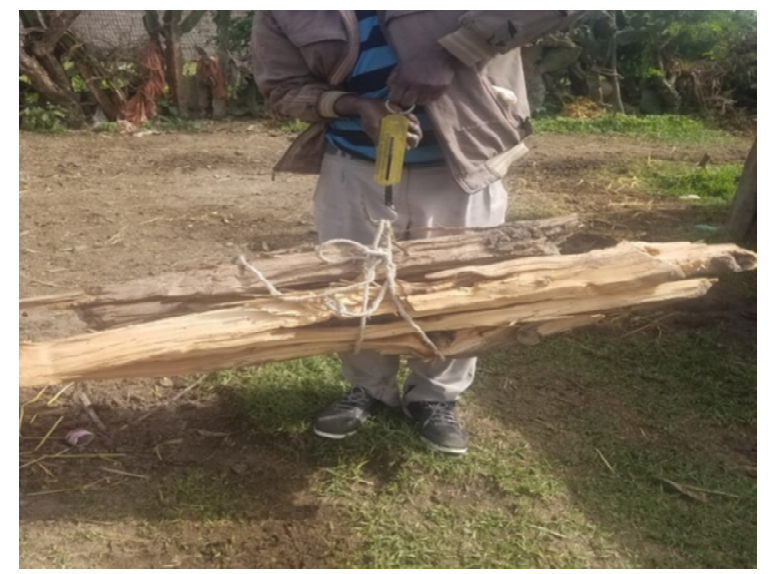

Sources: A). Photo from Gelama Hebano, 2018

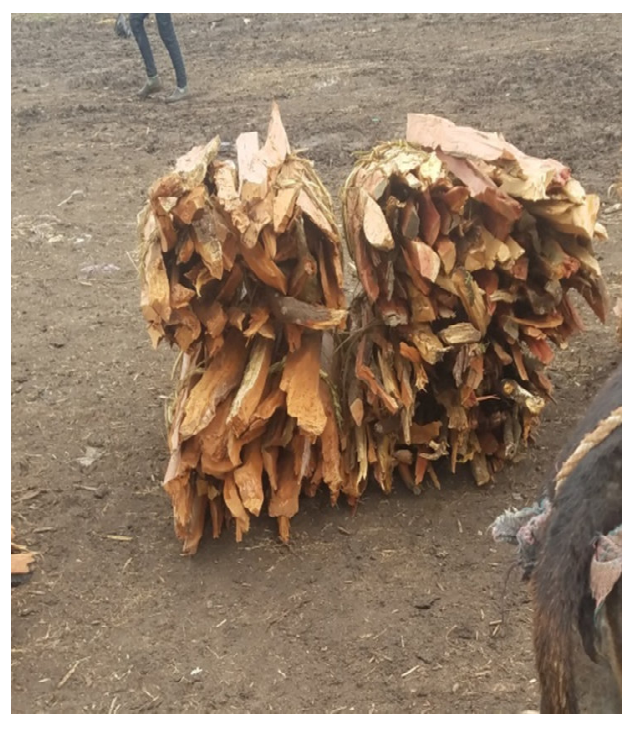

B). Photo from Oda nagesso Hebano, 2018

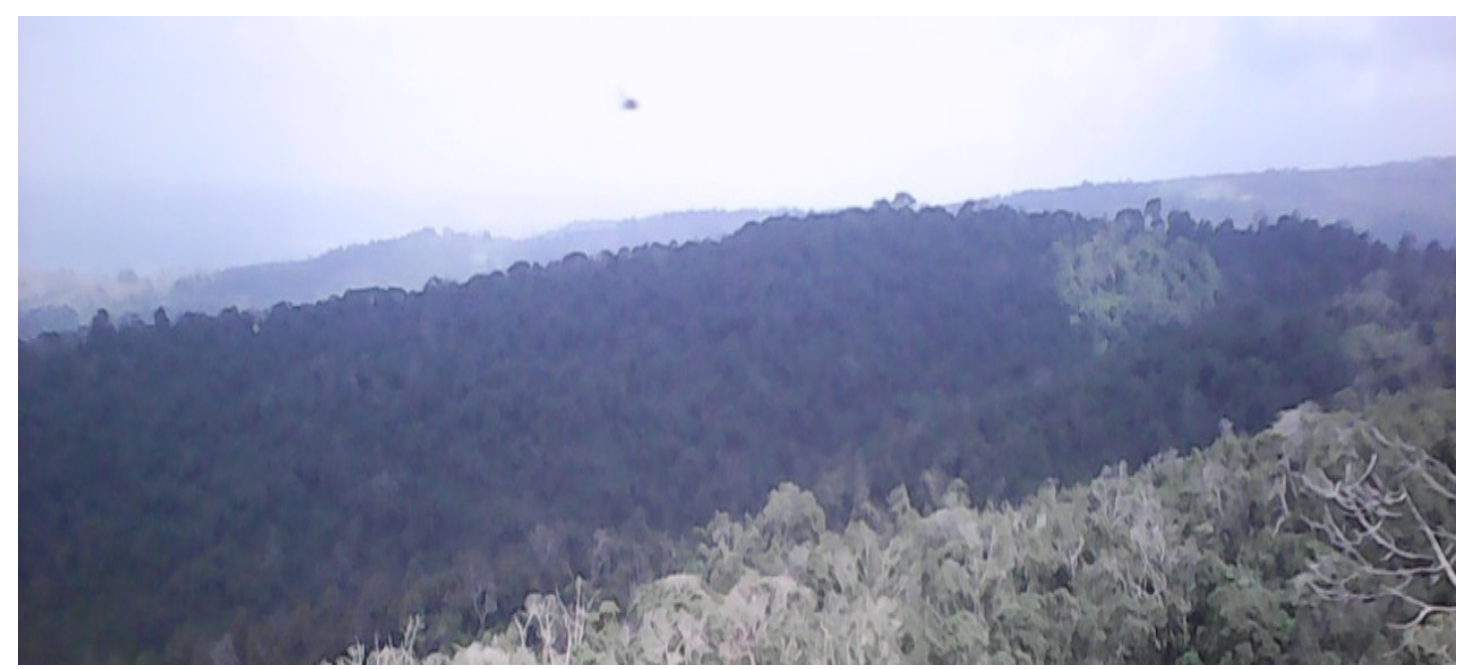

Source: - photo taken from Oda Nageso natural forest, 2018 